\title{
Influence of working pressure and spray nozzle on the distribution of spray liquid in manual backpack sprayers
}

\author{
Influência da pressão e da ponta de pulverização \\ na distribuição de caldas em pulverizadores costais manuais
}

\author{
Alcides Marangoni Junior ${ }^{1 *}$ (D), Marcelo da Costa Ferreira'

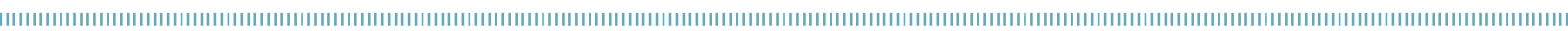

\begin{abstract}
Manual backpack sprayers are widely used in rural properties in Brazil. However, studies that assess their working characteristics, especially spray tip models and working pressure conditions, are scarce. Thus, the aim of this study was to assess how much the working pressure and spray tips influence the distribution quality of phytosanitary spray solutions in manual backpack sprayers. Four spray nozzles (standard flat-fan Magnojet TP11002, turbo flat-fan TeeJet TT11002, hollow-cone TeeJet TXA8002, and disc-core) were assessed in a patternator table at 1, 2, 3, and 4 bar. Analyses of spray distribution profile were performed by symmetry and the coefficient of variation (CV) analysed by the Tukey's test $(p<0.05)$. Spray tip models and working pressure influenced in more than $100 \%$ the distribution uniformity values of spray solution and in about $50 \%$ the useful range of the phytosanitary treatment. Among the models assessed in this study, the turbo flat-fan spray nozzle presents the best set of characteristics to be indicated for manual backpack sprayers aiming at field phytosanitary treatments.
\end{abstract}

KEYWORDS: disc-core spray nozzle; flat-fan spray nozzle; hollow-cone spray nozzle.
RESUMO: O uso de pulverizadores costais manuais no Brasil é amplamente disseminado em propriedades rurais. Entretanto, sáo escassos os trabalhos de pesquisa que avaliem as suas características de trabalho, sobretudo modelos de ponta de pulverização e condições de pressão de trabalho. Desta forma, o objetivo deste trabalho foi avaliar quanto os modelos de pontas e a pressão de trabalho influenciam na qualidade da distribuição de caldas fitossanitárias com pulverizadores costais manuais. Foram avaliados em mesa de deposição quatro modelos de pontas de pulverização (jato plano convencional Magnojet TP 11002; jato plano defletor Teejet TT 11002; jatos cônicos vazios TeeJet TXA 8002 e "chapinha” original), a 1, 2, 3 e 4 bar de pressão. As análises do perfil de distribuição dos jatos foram realizadas por simetria e o coeficiente de variação analisado pelo teste de Tukey $(\mathrm{p}<0,05)$. Os modelos de pontas de pulverizaçáo e a pressáo de trabalho influenciaram em mais de $100 \%$ os valores de uniformidade de distribuiçáo da calda, e cerca de $50 \%$ na largura da faixa útil de tratamento fitossanitário. Dentre os modelos avaliados neste trabalho, o de jato defletor é o que apresenta o melhor conjunto de características para ser indicado a equipar os pulverizadores costais manuais para os tratamentos fitossanitários de campo.

PALAVRAS-CHAVE: disco difusor de cerâmica; ponta de jato plano; ponta de jato cônico. 


\section{INTRODUCTION}

Brazil has more than 7 million farms, and approximately one third are smaller than 10 acres in size (DIEESE, 2006; BRASIL, 2015). Even small farms have a need for mechanization not only to maintain the feasibility of their activities, despite their limited availability of labor, but also to increase their production capacity and efficiency (KIENZLE et al., 2013).

In smaller farms, smaller machines are used in crops; for example, portable equipment such as manual backpack sprayers (KIENZLE et al., 2013). However, this type of equipment is common on farms of all sizes, and it is used for various activities, in basic chores or in small services. It is unusual for a farm not to have at least one manual backpack sprayer (CASALI, 2015). Thus, in Brazil, these devices are sold to thousands and used by millions on a daily basis.

However, they are not always used according to the best agronomic practices; there is a need for development of operational procedures, adequacy of accessories and improvement of ergonomic aspects (FREITAS, 2006; SASAKI et al., 2013; VITÓRIA et al., 2014).

One of their components, the spray nozzle tip, is particularly important because it is responsible for production and distribution of droplets, which can be considered the most important item of sprayers (MATUO, 1990).

In manual backpack sprayers, the usual original equipment manufacturer (OEM) tips are known as disc-core. They consist of an orifice disc associated with a core with skewed holes or passageways, responsible for helical motion of the liquid.

When passing through the region between the core and the disc, the liquid in helical motion is released through the orifice of the disc toward the air, whose resistance results in fragmentation of the liquid into droplets broadcast at a 360-degree angle to the nozzle. This type of fragmentation and distribution is known as "cone spray". The pattern of liquid distribution by spray nozzle tips has been assessed and compared to the models known as flat spray tip or flat fan spray tip. The sprays of such tips usually have a more uniform and symmetrical pattern; in addition, they pose lower risks of losses caused by drift (BUTLER-ELLIS; TUCK, 1999; ROMÁN et al., 2009; GRIESANG et al., 2017).

The operating pressure of sprayers is directly associated with droplet size; the higher the pressure, the smaller the droplet size. Pressure also interferes in spray angle and coverage; thus, they are supposed to be used at adequate pressure levels (CAMARA et al., 2008; TEEJET TECHNOLOGIES, 2013).

In the literature, there is a shortage of scientific studies on standard use of manual backpack sprayers with a "disc-core" nozzle tip, at the operating pressures used in these devices, which entails inaccurate recommendations for phytosanitary treatments.

Therefore, the aim of this research was to evaluate how spray nozzle tip models and operating pressure levels may affect the quality of distribution of phytosanitary spray solutions with manual backpack sprayers.

\section{MATERIAL AND METHODS}

To assess spray volume distribution, artesian well water was used from the water supply system of the School of Agrarian Sciences, São Paulo State University (FCAV-UNESP, Campus of Jaboticabal, São Paulo, with $0.1 \%$ of mineral oil adjuvant (Nimbus, Syngenta Crop Protection Ltda.), as recommended by the FOOD AND AGRICULTURE ORGANIZATION (FAO, 1998).

The spray mixture was prepared in a $20 \mathrm{~L}$ stainless steel tank, pressurized with compressed air through an MSV-5,2 VL 130 compressor (Metalúrgica Schulz S.A.).

Four spray tip models were evaluated: standard flat spray (Magnojet TP 11002 - MAG); turbo flat-fan spray (Teejet TT 11002 - TT); hollow cone spray (TeeJet TXA 8002 - TXA); and "disc-core" model with an OEM diffuser of manual backpack sprayers (Máquinas Agrícolas Jacto S/A. - CHAP).

Spray volume distribution was assessed using a spray table constructed from corrugated metal sheet having 67 troughs 2.5 $\mathrm{cm}$ apart, forming a swath with $167.5 \mathrm{~cm}$ in width (WHO, 1976). The spray table was tilted. A total of 61 test tubes (100 $\mathrm{mL}$ ) were placed at the bottom of the spray table to collect the spray mixture.

The nozzle tips being assessed were placed at the center of the table, at $50 \mathrm{~cm}$ from the ground, according to the recommendation of the FAO (1998). Spray volume distribution was assessed for each treatment. Spraying was performed until the test tubes of the central troughs (which received the largest amount of spray) reached $90 \%$ of their maximum volume capacity. Then, spray volume was recorded in each test tube. Spray volume was determined on the basis of the three replicates collected for each spray nozzle tip and operating pressure.

The collected volumes were used to determine the CVs of volumes collected within a previously defined swath (FAO, 1998), and the treated swath was determined by defining a spray volume distribution profile for each nozzle tip tested at pressures of 1,2, 3 and 4 bar.

The values for calculation of the $\mathrm{CV}$ and swath width were standardized between posterior edges of spray volume distribution, with a minimum of $60 \%$ of the average spray volume, considered as the treated usable swath. This percentage was defined so as not to undermine the phytosanitary control of the target to be controlled by the treatment (FERREIRA et al., 2009).

Spray volume distribution was expressed graphically through the analysis of symmetry of the volume collected on the right and left of the central position of the nozzle on the spray table, compared with the coefficient of determination $\left(\mathrm{R}^{2}\right)$. It was considered as symmetrical when the values were higher than 0.96 (FERNANDES et al., 2007).

The experiment used a factorial design with two factors (pressure and tip) in a completely randomized design (DIC) with 3 replicates. 
The F-test was used to compare the CV values for the definite swath width and the swath width which corresponds to $60 \%$ of the total volume applied, from the $20 \%$ percentile to $80 \%$ percentile, as well as the swath width $(\mathrm{cm})$ which corresponds to $60 \%$ of the volume. The means were compared by Tukey's test $(\mathrm{p}<0.05)$. The statistical analyses were performed using the statistical software program AgroEstat (BARBOSA; MALDONADO JUNIOR, 2011).

\section{RESULTS AND DISCUSSION}

The spray volume distribution profile of the nozzle tip models is characterized by an uneven spray distribution (Fig. 1), featuring an unimodal pattern for the flat spray (MAG) and turbo flat-fan spray (TT) models, and a bimodal pattern for the hollow cone (TXA) and "disc-core" models. Operating pressures interfered in distribution. In general, they increased the treated swath and decreased irregularities, except for the TT model, which showed no visible differences after variations in pressure. The flat spray models presented a larger width of the treated swath, compared to the cone spray models. The widest swath was found for the TT model while the narrowest was found for the "disc-core" model.

Uneven spray distribution is the characteristic pattern of spray tips and the most widely used. This pattern requires overlapping sprays of adjacent nozzles (MATUO, 1990; MATTHEWS et al., 2014). In spray booms, overlapping sprays are recommended by manufacturers as a safety margin, with a CV usually around 5\% (FERNANDES et al., 2007).

When individual nozzle tips are used, there are no overlapping sprays, which reduces not only safety margins but also the edges of the application swath, since volume distribution
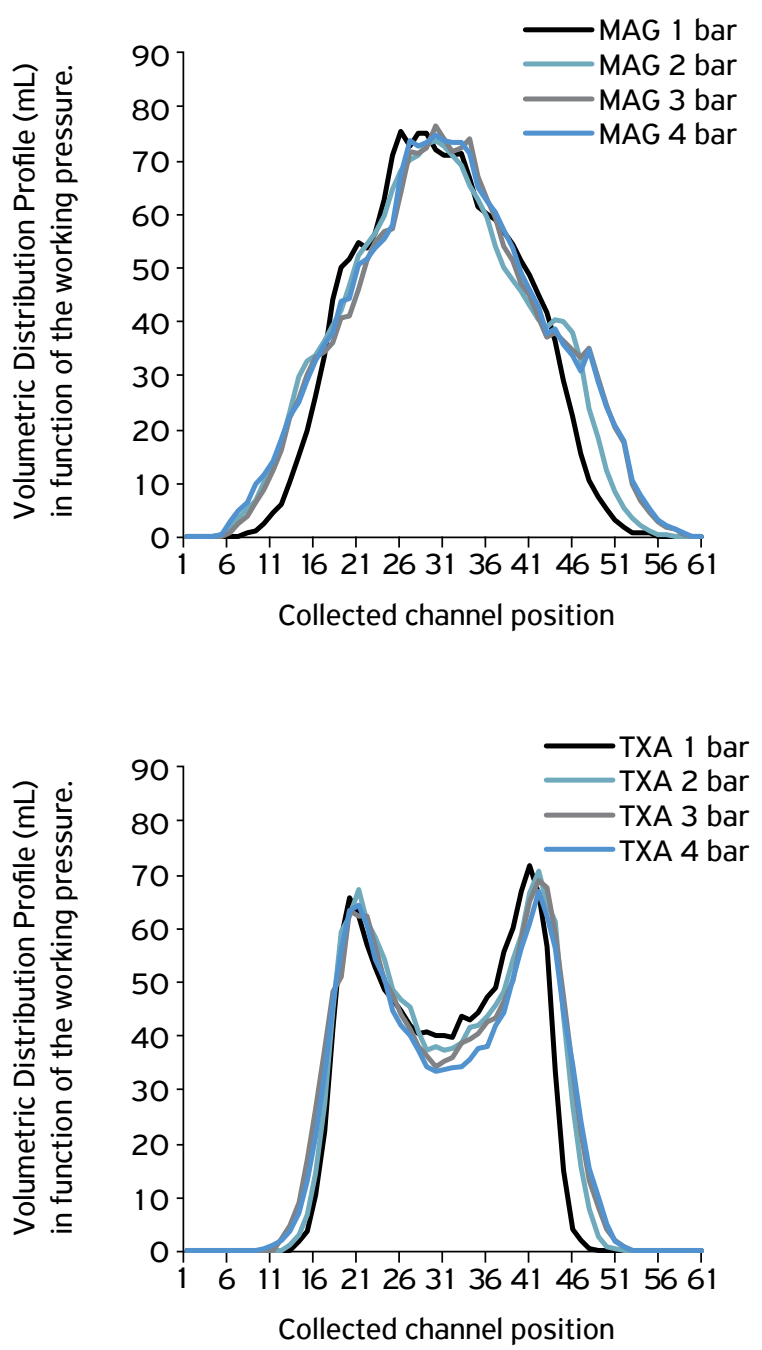
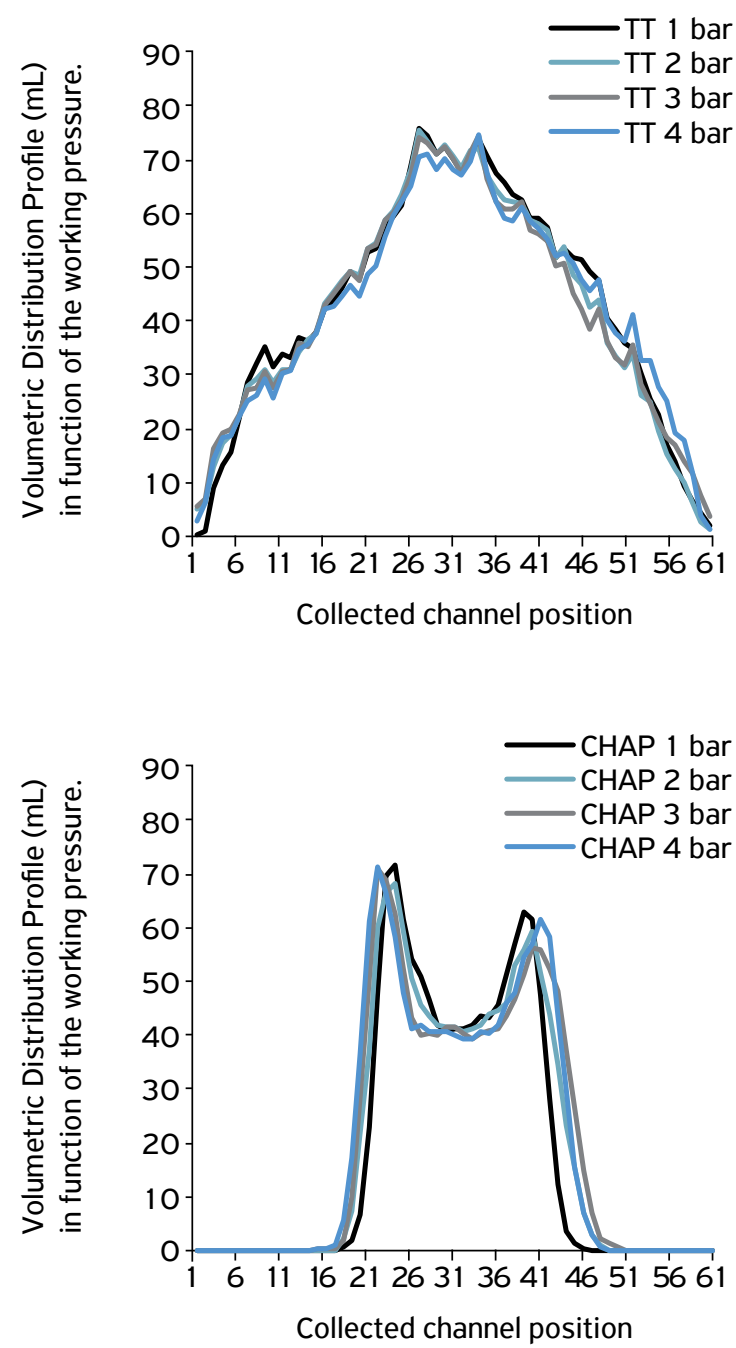

MAG: conventional flat fan (Magnojet TP 110015$)$ ) TT: deflector flat fan (Teejet TT 1 10015); TXA: hollow cone nozzle (TeeJet TXA 80015); CHAP: "disc-core" model with an OEM diffuser of hand pump backpack sprayers (Máquinas Agrícolas Jacto S/A).

Figure 1. Volumetric distribution profile of sprayed liquid by different spray nozzle models and working pressures by a hand pump backpack sprayer. 
changes as it moves away from the center of the spray. To prevent part of the treated area from receiving insufficient spray, the usable swath has to be determined for application, based on the largest volume released by the nozzle tip. These swaths commonly vary according to working pressure and mixture in use (CAMARA et al., 2008), because of the force applied to release the liquid through the nozzle as well as the characteristic liquidity of the liquid itself. Considering the spray nozzle outflow and the spray volume distribution in a treated swath, distribution must be symmetrical to the nozzle flow path.

Spray symmetry was satisfactory for the models of spray nozzle tips assessed in this study (Fig. 2), with $\mathrm{R}^{2}$ higher than 0.96 , which are considered symmetrical (FERNANDES et al., 2007; FERREIRA et al., 2007; ROMÁN et al., 2010), except for the "disc-core" model, which presented a $\mathrm{R}^{2}$ value lower than 0.94 .

For the TT and TXA models, the angular coefficients of the regression equation of spray volume distribution were close to 1 . This means that spray volume distribution was symmetrical to the nozzle flow path. Angular coefficient was 0.91 for the MAG model and 0.81 for the "disc-core" model, indicating a deviation in volume distribution of the spray mixture, with the highest value found for the "disc-core" model.

Symmetry is also a characteristic of each type of spray nozzle (MATUO, 1990; MATTHEWS et al., 2014). However, symmetry may vary, depending not only on the standards and quality control of manufacturers but also on careful handling. The nozzle tip models that produce smaller droplets, e.g., the models TXA and "disc-core", are usually chosen by farmers because they result in greater target coverage (COURSHEE, 1967). However, as smaller droplets are more prone to evaporation and wind drag, they commonly result in lower distribution uniformity of the mixture on the plants (ROMÁN et al., 2009).

Among the three types of spray tips in use, there were differences in application swaths (Fig. 3). Among the three replicates assessed for each model, there were variations of 6 to $8 \%$ in spray nozzle outflow between nozzle tips 1 and 3,
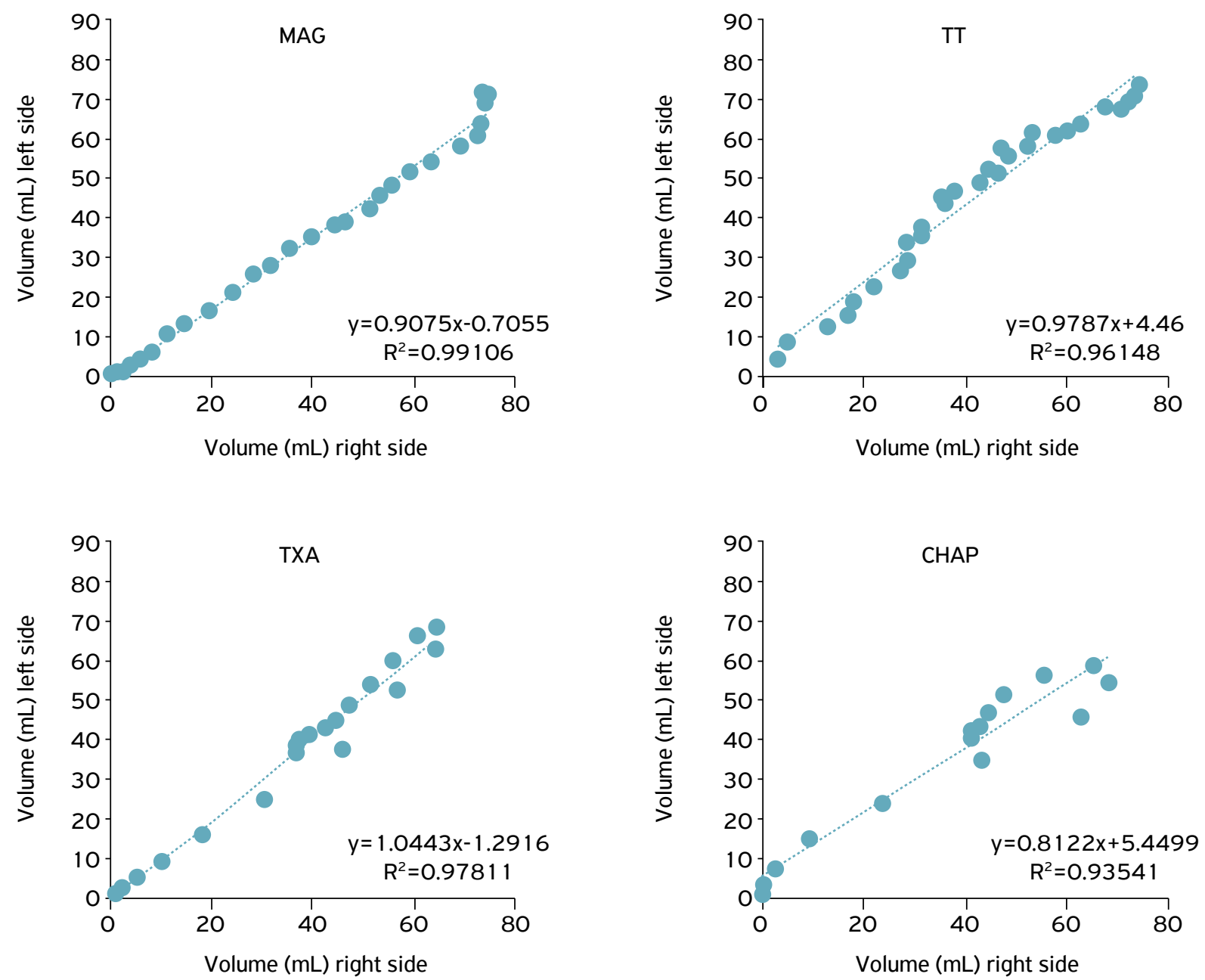

MAG: conventional flat fan (Magnojet TP 110015$)$; TT: deflector flat fan (Teejet TT 110015); TXA: hollow cone nozzle (TeeJet TXA 80015); CHAP: "disc-core" model with an OEM diffuser of hand pump backpack sprayers (Máquinas Agrícolas Jacto S/A).

Figure 2. Symmetry of volumetric distribution of sprayed liquid obtained from spray nozzle models of hand pump backpack sprayers. Average of working pressures (1, 2, 3 and 4 bar). 
for the MAG model; from 8 to $14 \%$ between tips 1 and 3, for the TT model; between 3 and $15 \%$ between tips 2 and 3 , for the TXA model.

However, for the latter model, there was no definite variation between the tips, with alternations between maximum and minimum variations. For the "disc-core" model, there were variations between the tips of up to $26 \%$ of the treated swath, also without a definite pattern between tips and pressures, with alternations between the greatest variations (Fig. 3). Among the models, there was an increase in the treatment swath with increased working pressure, except for the TT model.

For the TXA and CHAP models, there was an increase of the swath until the pressure of 3 bar. However, variation of application characteristics between tips of the same model is not desired, although it is a recurring event (CAMARA et al., 2008). Importantly, manufacturers must follow high quality control procedures to prevent significant differences among products. Variation in quality interferes with distribution of the spray mixture on the crops to be treated.

It should be noted that the spray nozzle models have affected the distribution of phytosanitary spray mixtures, for each operating pressure assessed (Fig. 4). For the fixed swath, the CHAP model presented the highest mean values for $\mathrm{CV}$ (around 20\%).

For the CHAP model and the hollow cone (TXA) model, results were different with respect to increase of pressure. The CV was greater with the increase of pressure for the TXA tip, but it decreased for the CHAP model. For both of them, however, there was a significant variation among the replicates assessed. The standard deviation of data shows that the difference between pressure levels for the "disc-core" and TXA models was lower than the variation among replicates of the same model (Fig. 4).

The flat spray models presented lower $\mathrm{CV}$ values among the replicates of each model and pressures assessed (Fig. 4). Thus, there were no differences among the pressure levels within each tip model and tips for pressures of 3 and 4 bar. For the pressure values of 1 and 2 bar, there was a significant difference between the tip models known as "disc-core" and TT (turbo flat-fan spray).

For the hollow cone models, values reported in the literature are even higher than those found in this research, because of the characteristics of the model and form of spray distribution and droplet formation. For CDD (ceramic diffuser disc) models, CVs were found to be more than $14 \%$ for new tips and more than $24 \%$ for used tips at a pressure of 4 bar (VITÓRIA et al., 2014). This may indicate poor quality of the material and even the need for a replacement of the tips being used. To maintain the quality of distribution, a CV value of up to $15 \%$ is considered to be acceptable (WOLF; SMITH, 1979; SMITH, 1992).

Variations were unsuitable for distribution for the values found for the model TXA at pressures above 1 bar and for the "disc-core" model at all pressure values analysed. Several authors have found that the most suitable $\mathrm{CV}$ value for spraying is around $10 \%$, as there is more satisfactory uniformity (ROTH et al., 1985; PERECIN et al., 1994, 1998). In the condition of this research, only the TT model had the most suitable distribution pattern.

For the $60 \%$ spraying swath deemed usable (excluding $20 \%$ of the volume collected from each side edge), there
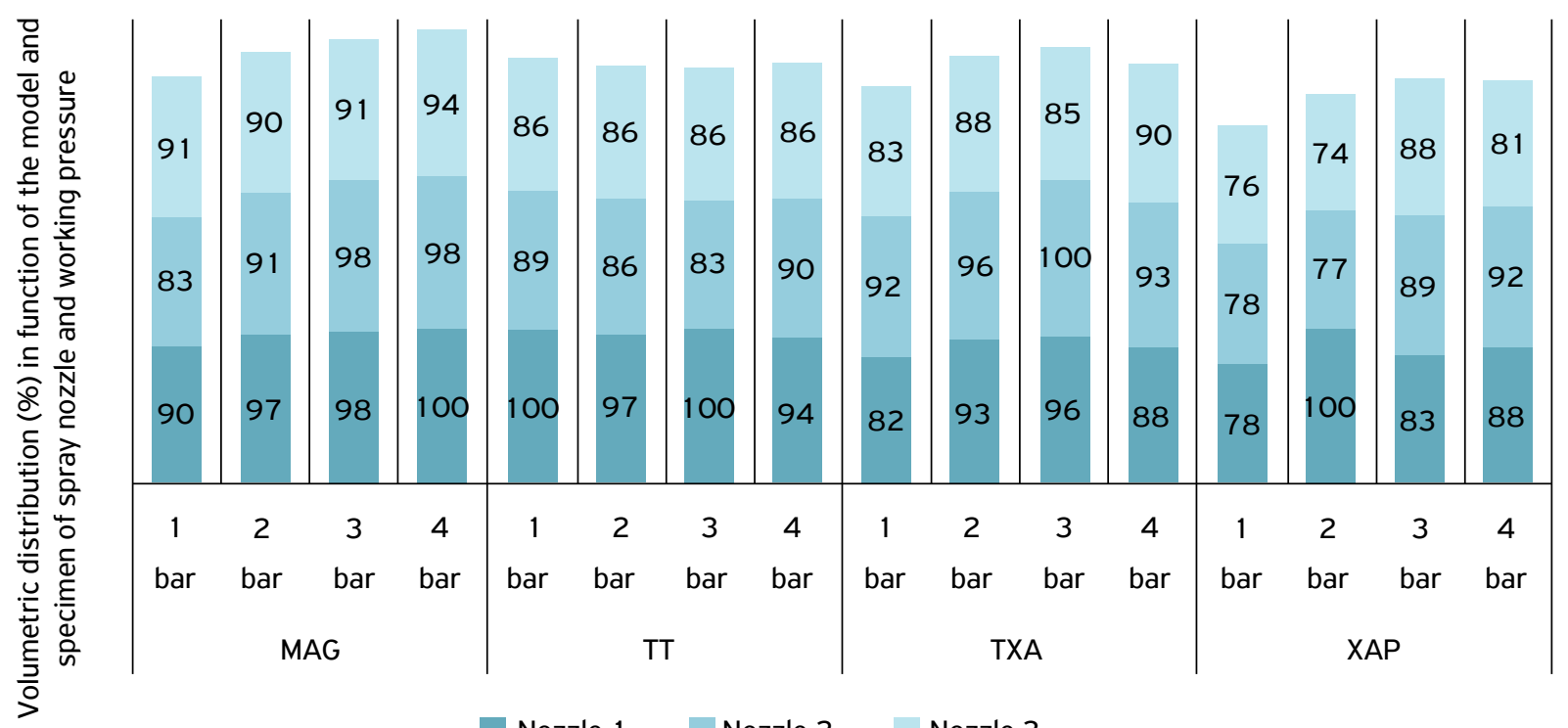

Nozzle 1

Nozzle 2

Nozzle 3

MAG: conventional flat fan (Magnojet TP 1 10015); TT: deflector flat fan (Teejet TT 1 10015); TXA: hollow cone nozzle (TeeJet TXA 80015); CHAP: "disc-core" model with an OEM diffuser of hand pump backpack sprayers (Máquinas Agrícolas Jacto S/A).

Figure 3. Percentual volumetric distribution of sprayed liquid obtained from four models and three specimen of spray nozzles in four working pressures by a hand pump backpack sprayer. 
was no difference between tips, at the pressure levels of 1, 2 and 3 bar and between pressure levels for the MAG, TT and CHAP tips (Fig. 5).

For the hollow cone (TXA) model, the pressure level of 4 bar showed a higher CVthan the pressure level of 1 bar (Fig. 5). For this model, the CV was also higher than for the other spray tip models evaluated at the pressure level of 4 bar. On average, the CVs were equal to or less than $15 \%$ for the models TT (at all pressure levels), MAG (at pressure levels of 1, 2 and 4 bar), TXA (at 1 bar) and CHAP (at 1 bar).

The TXA model has always been operated at pressure levels of 5 bar or higher (TEEJET TECHNOLOGIES, 2014). In recently published catalogs, this model is offered with working pressure starting at 2 bar. However, as noted, changes in operating pressure require more careful handling of manual backpack sprayers (Fig. 5).

Hollow cone spray nozzles, as a rule, form fine droplets because of the helical motion of liquid inside the nozzle body, which results in the conical shape of the spray. This whole process usually requires higher pressure for formation of fine droplets, in comparison to flat spray models (SPANOGHE et al., 2007).

When the spray mixture is pumped with the hand lever of manual backpack sprayers, it is fairly difficult to maintain constant pressure above 3 bar. As the TXA nozzle model is sensitive to variations within this pressure range, the recommendation of use of this type of spray nozzle may be restricted to this type of sprayer. For all other models, sensitivity was not enough to result in significant differences (Fig. 5).

When $60 \%$ of the spray volume was considered to determine the usable application swath, there was no difference among pressure levels for the TT and TXA models (Fig. 6). For the MAG model, the pressure of 4 bar provided a wider treatment swath than the pressure of 1 bar. For the CHAP model, the pressure levels of 3 and 4 bar resulted in significantly wider swaths than the pressure of 1 bar.

The width treated by the TT model (about 61 to $66 \mathrm{~cm}$ ) was significantly greater and represented, respectively, an increase of 30 to $50 \%$ compared to the MAG (38 to $47 \mathrm{~cm}$ ) and CHAP (44 to $51 \mathrm{~cm}$ ) models.

The TXA model resulted in a wider usable swath than the CHAP model, and neither of them differed from the MAG model. The TT model has a flat-fan spray formation pattern which has the characteristic of opening the spray angle even at lower pressures (PERECIN et al., 1998; ROMÁN et al., 2010; TEEJET TECHNOLOGIES, 2014).

Thus, the swath treated with the TT spray nozzle tip had good uniformity, with greater coverage than the other models. Thus, for the sprayer used in the most common

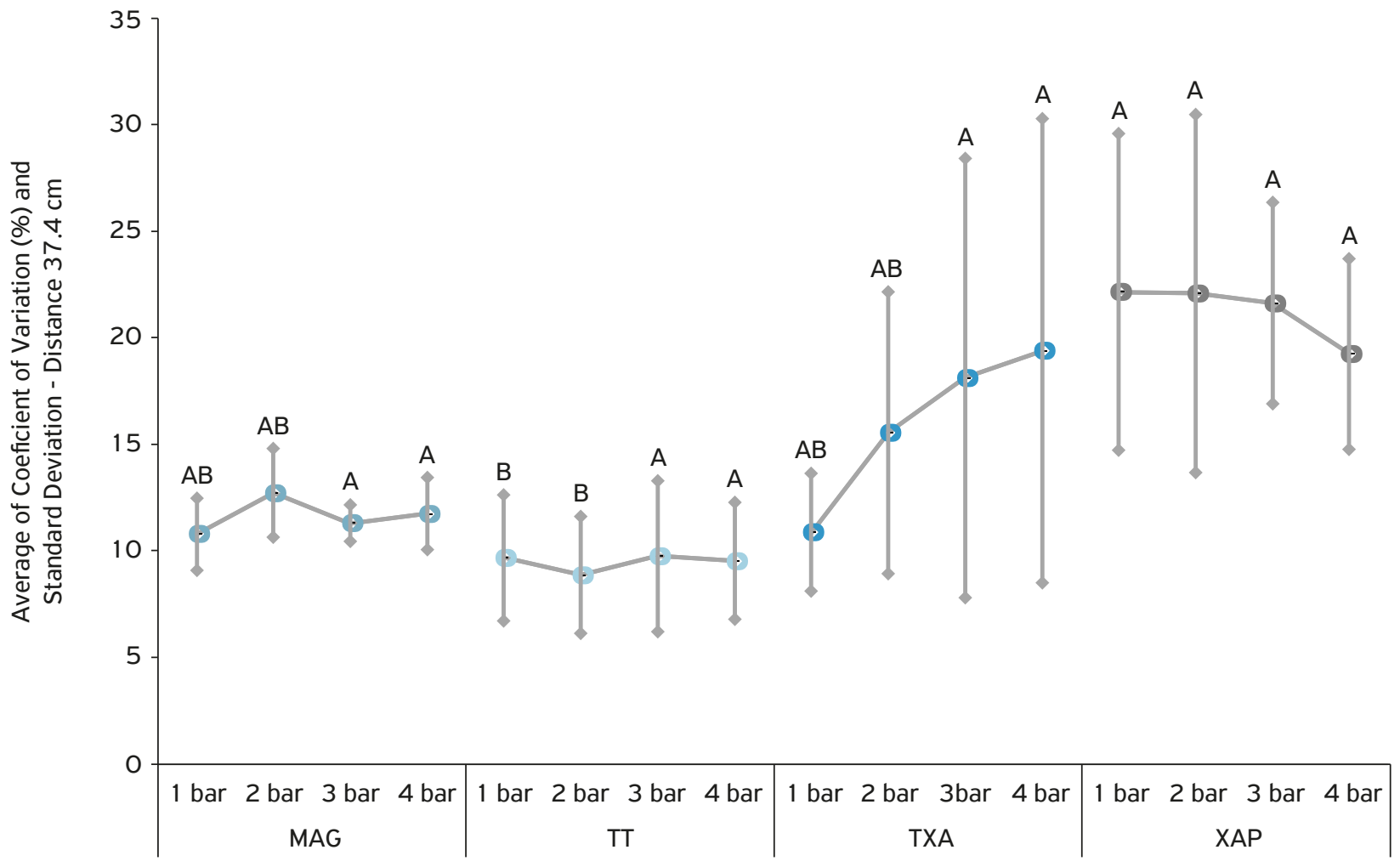

MSD $(5 \%)=12.26$. MAG: conventional flat fan (Magnojet TP 110015); TT: deflector flat fan (Teejet TT 1 10015); TXA: hollow cone nozzle (TeeJet TXA 80015); CHAP: "disc-core" model with an OEM diffuser of hand pump backpack sprayers (Máquinas Agrícolas Jacto S/A).

Figure 4. Average values of coefficient of variation (\%), and each standard deviation of sprayed liquid distribution obtained from four spray nozzle models and four working pressures (1, 2, 3 and 4 bar), by a hand pump backpack sprayer. Means followed by the same capital letter do not differ between themselves (between nozzles into each working pressure), by Tukey test $(p<0.05)$. 


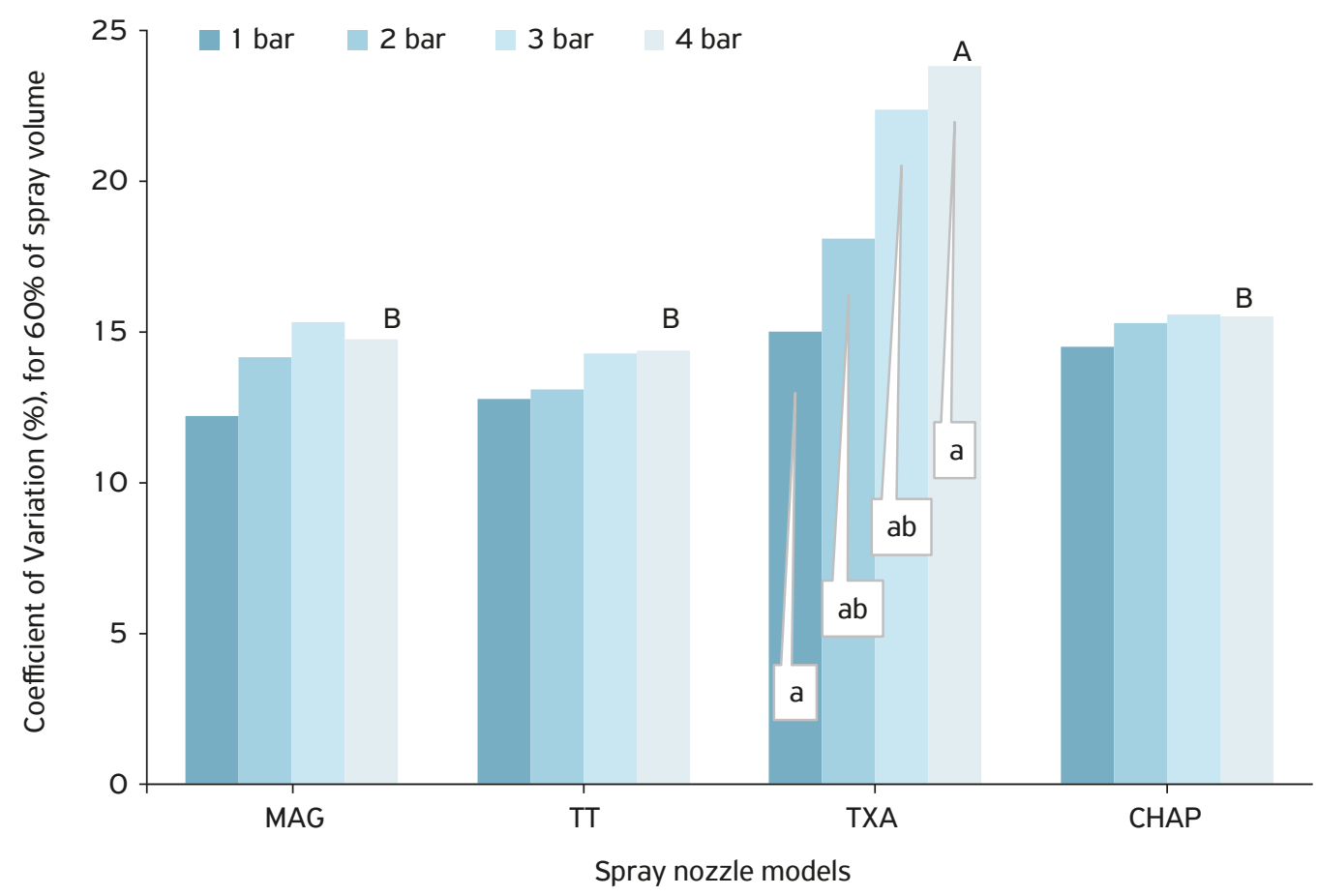

MSD $(5 \%)=8.17$. MAG: conventional flat fan (Magnojet TP 110015$) ;$ TT: deflector flat fan (Teejet TT 110015); TXA: hollow cone nozzle (TeeJet TXA 80015); CHAP: "disc-core" model with an OEM diffuser of hand pump backpack sprayers (Máquinas Agrícolas Jacto S/A).

Figure 5. Average values of coefficient of variation (\%) of sprayed liquid distribution obtained from four spray nozzle models and four working pressures ( $1,2,3$ and 4 bar), by a hand pump backpack sprayer. Means followed by the same letter (uppercase to nozzles and lowercase to pressures) do not differ between themselves, by Tukey test $(p<0.05)$.

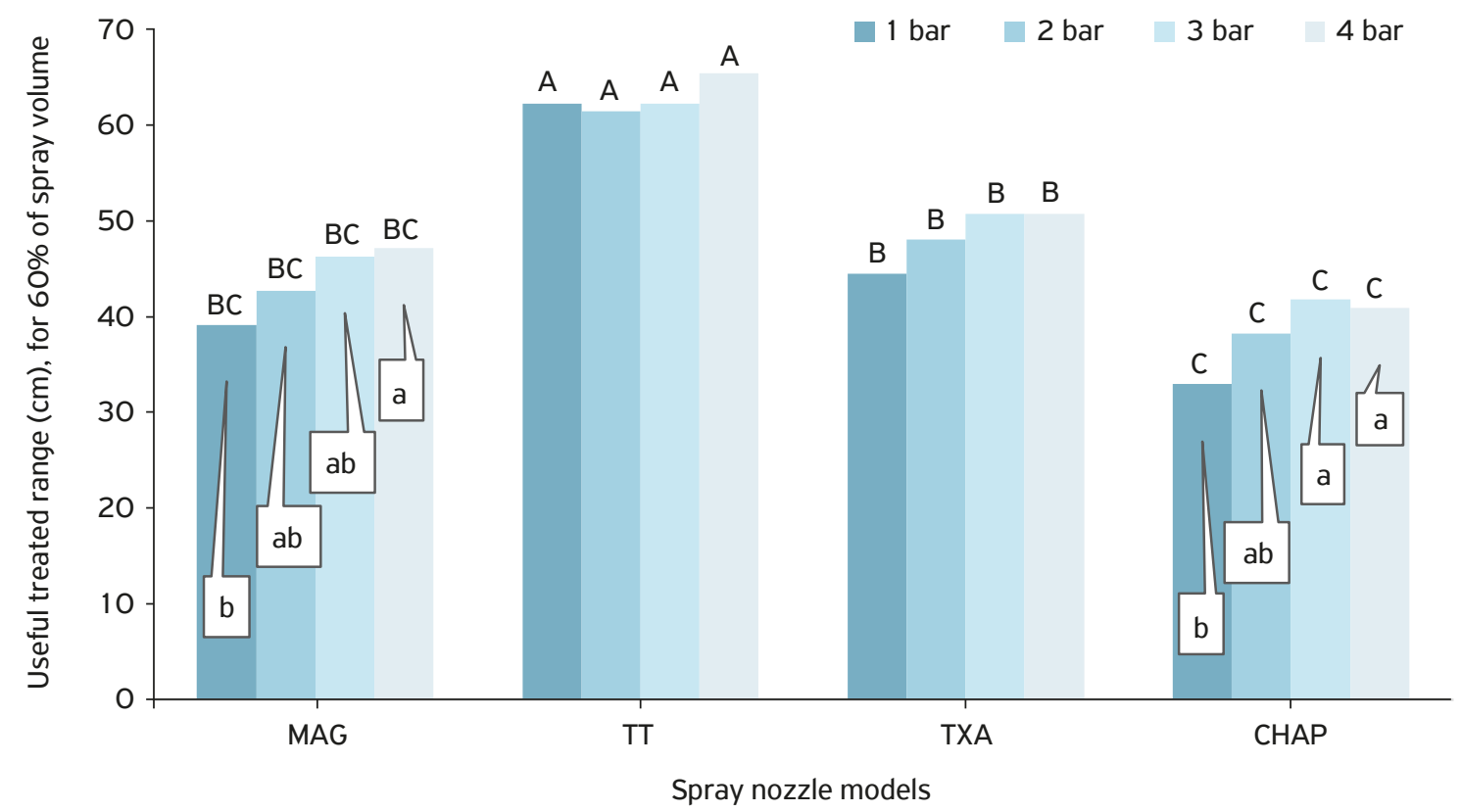

MSD $(5 \%)=7.17$. MAG: conventional flat fan (Magnojet TP 1 10015); TT: deflector flat fan (Teejet TT 110015); TXA: hollow cone nozzle (TeeJet TXA 80015); CHAP: "disc-core" model with an OEM diffuser of hand pump backpack sprayers (Máquinas Agrícolas Jacto S/A).

Figure 6. Average values of useful treated range $(\mathrm{cm})$ of sprayed liquid distribution obtained from four spray nozzle models and four working pressures (1, 2, 3 and 4 bar), by a hand pump backpack sprayer. Means followed by the same letter (uppercase to nozzles and lowercase to pressures) do not differ between themselves, by Tukey test $(p<0.05)$. 
configuration, fitted with only one spray tip, the deflector model (TT) showed the best results in terms of quality and quantity of work done, since it presents the smallest variation and the largest working width, which may be suitable for phytosanitary applications.

CHAP spray tips are the ones usually fitted to manual backpack sprayers. Thus, it is clear that their quality and operational capacity can be improved for this activity. This model at the pressure of 2 bar has resulted in a treated swath of 38 $\mathrm{cm}$ compared to a swath of $61 \mathrm{~cm}$ for the turbo flat-fan spray model (TT). The best performance results achieved for pressures 3 and 4 bar imply effort limitations for the operator with the manually-operated sprayer. To maintain the operation of the sprayer under these pressure levels, pumping requires more effort from the operator.

Mechanisms that could provide more power to the sprayer, for example, sprayers fitted with electric engines, can be used to increase pumping capacity without requiring greater effort from the operator. These alternatives are already available and can also be used to increase pumping capacity (VITÓRIA et al., 2014). This could even favor the use of more than one nozzle connected to the sprayer boom, which can increase spraying uniformity and quality, as there may be larger plants that require wider application swaths. On the other hand, only increasing the operating pressure may not be a good idea, because it increases wear of both spray nozzles and the equipment itself, therefore reducing its lifetime.

In terms of market prices, the CHAP spray nozzle model is sold regionally for "US\$ 0.86 " (eighty-six cents of a dollar), the standard flat spray (MAG), for "US\$ 0.71 " (71 cents of a dollar), and the turbo flat-fan spray model (TT), for "US\$ 3.99" (three dollars and ninety-nine cents). When qualitative and operational aspects are taken into account, these differences can justify the use of models with better performance. However, other adjustments to the equipment could be evaluated, such as modification of the pumping system using wider pistons, to increase the motion capacity of liquids.

\section{CONCLUSIONS}

The turbo flat-fan spray model (TT) had the best performance in comparison to the standard flat spray (MAG), hollow cone spray (TXA) and "disc-core" (CHAP) models. Thus, it is the most suitable to be fitted to manual backpack sprayers for phytosanitary treatments.

In manual backpack sprayers, working pressure and spray nozzle tip models have affected spray distribution uniformity values by more than $100 \%$, and the width of the usable swath of the phytosanitary treatment by approximately $50 \%$.

\section{REFERENCES}

BARBOSA, J.C.; MALDONADO JÚNIOR, W. Software AgroEstat Sistema de análises estatísticas de ensaios agronômicos. Jaboticabal: Universidade Estadual Paulista, 2011.

BRASIL. Cadastro Rural. Cadastro de Imóveis Rurais (Cafir) da RFB conta com aproximadamente 7.442.515 imóveis ativos. 2015. Available from: <http://www.cadastrorural.gov.br/estatisticas/ cafir-cadastro-de-imoveis-rurais/copy_of_total-de-imoveis-ativosno-cadastro-de-imoveis-rurais-cafir-da-rfb-sao-7-442.515>. Access on: Mar. 192018.

BUTLER-ELLIS, M.C.; TUCK, C.R. How adjuvants influence spray formation with different hydraulic nozzles. Crop Protection, v.18, n.2, p.101-109, 1999. https://doi.org/10.1016/ S0261-2194(98)00097-0

CAMARA, F.T.; SANTOS, J.L.; SILVA, E.A.; FERREIRA, M.D.C. Volumetric distribution and spectrum of drops of hydraulic nozzles of plane jet of expanded strip XR1 1003. Engenharia Agrícola, v.28, n.4, p.740-749, 2008. http://dx.doi.org/10.1590/ So $100-69162008000400014$

CASALI, A.L. Mechanization for rural development: A review of patterns and progress. 2015. 127f. Thesis (Doctor's degree in Agricultural Engineering) - Centro de Ciências Rurais, Universidade Federal de Santa Maria, Santa Maria, 2015.

COURSHEE, R.J. Application and use of foliar fungicides. In: TORGESON, D.C. (Ed.). Fungicide: An advanced treatise. New York: Academic Press, 1967. p.239-286.

DEPARTAMENTO INTERSINDICAL DE ESTATÍSTICA E ESTUDOS SOCIOECONOMMICOS (DIEESE). Anuário dos trabalhadores. 2006. Available from: <https:// www.dieese.org.br/anuario/2006/anuario2006.pdf>. Access on: Feb. 032018.

FERNANDES, A.P.; PARREIRA, R.S.; FERREIRA, M.C.; ROMANI, G.N. Caracterização do perfil de deposição e do diâmetro de gotas e otimização do espaçamento entre bicos na barra de pulverização. Engenharia Agrícola, v.27, n.3, p.728-733, 2007. http://dx.doi. org/10.1590/SO100-69162007000400016

FERREIRA, M.C.; COSTA, G.M.; SILVA, A.R.; TAGLIARI, S.R.A. Fatores qualitativos da ponta de energia hidráulica ADGA 110015 para pulverização agrícola. Engenharia Agrícola, Jaboticabal, v.27, n.2, p.471-478, 2007. http://dx.doi.org/10.1590/ so $100-69162007000300016$

FERREIRA, M.C.; DI OLIVEIRA, J.R.G.; DAL PIETRO, I.R.P.S. Distribuição da calda herbicida por pontas de pulverização agrícola utilizadas em áreas de reflorestamento com eucalipto. Engenharia Agrícola, v.29, n.2, p.267-276, 2009. http://dx.doi. org/10.1590/SO100-69162009000200010

FOOD AND AGRICULTURE ORGANIZATION OF THE UNITED NATIONS (FAO). Agricultural pesticide sprayers. v. 1 FAO Guidelines on equipment quality control and use. Rome: FAO, 1998. Available from: <http://www.fao.org/docrep/X2244E/X2244EOO.htm>. Access on: Mar. 192018. 
FREITAS, C.S. Manual na cultura do café no município de Caratinga-MG. 2006. 70f. Dissertation (Master's degree in Environmental Sustainability - Magister Scientiae) - Centro Universitário de Caratinga, Caratinga, 2006.

GRIESANG, F.; DECARO, R.A.; SANTOS, C.A.M.; SANTOS, E.S.; ROQUE, N.H.D.L.; FERREIRA, M.C. How much do adjuvant and nozzles models reduce the spraying drift? Drift in agricultural spraying. American Journal of Plant Sciences, v.8, n. 1 1, p.27852794, 2017. https://doi.org/10.4236/ajps.2017.811188

KIENZLE, J.; ASHBURNER, J.E.; SIMS, B.G. Mechanization for rural development: A review of patterns and progress. v.20. Rome: FAO, 2013. 364p.

MATUO, T. Técnicas de aplicação de defensivos agrícolas. 1. ed. Jaboticabal: FUNEP, 1990. 139p.

MATTHEWS, G.A.; BATEMAN, R.P.; MILLER, P.C.H. Pesticide application methods. London: Longman, 2014. 556p.

WORLD HEALTH ORGANIZATION. Material de lucha contra los vetores. Genebra: WHO, 1976. 189p.

PERECIN, D.; PERESSIN, V.A.; MATUO, T.; BARBOSA, J.C.; PIO, L.C.; BRAZ, B.A. Padrões de distribuição obtidos com bicos Twinjet em função da altura e do espaçamento entre bicos. Engenharia Agrícola, v.14, p.19-30, 1994.

PERECIN, D.; PERESSIN, V.A.; MATUO, T.; BRAZ, B.A; PIO, L.C. Padrões de distribuição de líquidos obtidos com bicos TF-VS4, TJ60-1 1006 e TQ 15006 em mesa de prova. Pesquisa Agropecuária Brasileira, v.33, n.2, p.175-182, 1998.

ROMÁN, R.A.A.; CORTEZ, J.W.; DA COSTA FERREIRA, M.; DI OLIVEIRA, J.R.G. Coverage of soybean crop by spraying liquid due nozzles and spraying volume. Scientia Agraria, v.10, n.3, p.222-232, 2009.

ROMÁN, R.A.A.; FERREIRA, M.C.; CARVALHO, G.F.G.; BAGGIO, M.V. Spraying distribution, symmetry of fan and droplet size to spray nozzles TF-VS2. Planta Daninha, v.28, n.4, p.897-905, 2010. https://doi.org/10.1590/S0100-83582010000400023

ROTH, L.O.; WHITNEY, R.W.; KUHLMAN, D.K. Application uniformity and some non-symmetrical distribution patterns of agricultural chemicals. Transactions of the ASAE, v.28, n.1, p.47-50, 1985. https://doi.org/10.13031/2013.32200

SASAKI, R.S.; MARTINS TEIXEIRA, M.; EDUARDO NOGUEIRA, L.; BATISTA DE ALVARENGA, C.; MORAIS DE OLIVEIRA, M.V. Desempenho operacional de um pulverizador costal elétrico. Pesquisa Agropecuária Tropical, v.43, n.3, p.339-342, 2013. https://doi.org/10.1590/S1983-40632013000300015

SMITH, D.B. Uniformity and recovery of broadcast sprays using fan nozzles. Transactions of the ASAE, v.35, n. 1, p.39-44, 1992.

SPANOGHE, P.; SCHAMPHELEIRE, M.; VAN der MEEREN, P.; STEURBAUT, W. Influence of agricultural adjuvants on droplet spectra. Pest Management Science, v.63, n.1, p.4-16, 2007. https://doi.org/10.1002/ps.1321

TEEJET TECHNOLOGIES. A user's guide to spray nozzles. 2013. Available from: <http://teejet.it/media/40076/user\%27s\%20 guide\%20to\%20spray\%20nozzles_2013_lo-res-sequential. pdf>. Access on: Apr. 092018.

TEEJET TECHNOLOGIES. Catálogo 51 A-PT. 2014. p.164. Available from: <http://teejet.it/media/464368/cat51a_lo-res_ portuguese.pdf>. Access on: Apr. 092018.

VITÓRIA, E.L.; ROCHA NETO, F.C.; CHAGAS, K.; TEIXEIRA, M.M.; QUIRINO, A.L.S.; SANTIAGO, H. Distribuição volumétrica e espectro de gotas de pontas de pulverização de jato cônico vazio DDC2 novas e usadas. Revista Agro@mbiente on-Line, v.8, n.3, p.368376, 2014. http://dx.doi.org/10.18227/1982-8470ragro. v8i3.1831

WOLF, D.D.; SMITH, E.S. Uniformity of seed and fertilizer distribution with a hand-operated spinning spreader. Transactions of the ASAE, St. Joseph, v.22, n.4, p.761-762, 1979. 